DOI 10.1515/linpo-2016-0014

\title{
Functions of valency operators in Kamas
}

\author{
Gerson Klumpp \\ Institute of Estonian and General Linguistics, University of Tartu \\ e-mail: klumpp@ut.ee
}

\begin{abstract}
Gerson Klumpp. Functions of valency operators in Kamas. The Poznan Society for the Advancement of Arts and Sciences, PL ISSN 0079-4740, pp. 189-206

This article provides an account of the functional range of Kamas valency operators. Kamas is an extinct South Siberian language of the Samoyed branch of Uralic, which was in close contact with Turkic for many centuries. In the early $20^{\text {th }}$ century, Kamas had two valency operators: (i) -Ta derived transitive from intransitive verbs as well as causative from transitive verbs; and (ii) $-\bar{O}$ derived intransitive from transitive verbs; in addition the intransitivizer, probably departing from pairs like $e d \partial$ - 'hang up (tr.)' > ed-ö- 'hang (itr.)', had

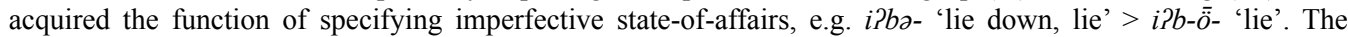
two markers may occur in combination in the order "increase-decrease" $(-T-\bar{O})$, but not vice versa. While on the one hand the valency operators may be understood as verb derivation morphemes proper, i.e. verbs derived with the suffixes $-T_{\partial}$ - and $-\bar{O}$ - are considered new lexical entries, their functional range also covers combinations with participles otherwise unspecified for voice. The valency decreaser $-\bar{O}$ occurs with participles of transitive verbs in order to specify P-orientation. The valency increaser - Ta has a variety of causative readings, among them causative-reflexive, causative-permissive, and causative-instrumental, and it also qualifies as a marker of control and/or characterizing activity. The discussion in this article is focused mainly on classificational issues.
\end{abstract}

Keywords: Southern Samoyed, valency derivation slot, Turkic contact, ambiguity of readings, control marking

\section{Introduction}

\subsection{Kamas}

Kamas belongs to the Selkup-Kamas sub-branch of Samoyed, and Samoyed is a branch of Uralic. Kamas was spoken in South Siberia, on the northern slopes of the East Sayan ridge, along the rivers Kan, Mana, Mina, and others. It was documented mainly between the mid $-19^{\text {th }}$ and early $20^{\text {th }}$ century, when the village of Abalakovo was visited by A. M. Castrén in 1847 and by K. Donner in 1912 and 1914. Lexical documentation had however already been started in the 18th century. After World War I the speech community 
shifted to Russian, and in the late 1960s and early 1970s, A. Künnap documented the Kamas spoken by rememberers; the last speaker died in 1989.

The Sayan Samoyed population had been exposed to Turkic assimilation until the second half of the $19^{\text {th }}$ century, and the name Kamas referred not only to Samoyed, but also to Turkic groups (see Pritsak 1959). Turkic influence seized after Russian had become the dominant language in the area. The documented language of the rememberers after the shift from Kamas to Russian shows strong Russian influence and differs considerably from that of the pre-shift period.

Kamas is an SOV language, agglutinative with vowel harmony, and converbal syntax. It kept the Samoyed features of the dual number, agreement of 3rd person objects, and a negation verb. Besides number, other nominal inflectional categories are case and person (possessive suffixes). The verb complex includes two derivational slots after the stem: the first one contains inherited suffixes with different functions, the second slot contains aspect suffixes grammaticalized from auxiliary verb constructions (see Klumpp 2005). The derivation slots are followed by tense/mood markers, or by non-finites (infinitive, participles, converb); person markers follow the tense/mood markers. Intransitive subjects (S) and transitive subjects (A) go unmarked, direct objects (O) are unmarked when new, but when given in the accusative case, indirect objects are in the lative case. Given direct objects agree on the verb where this is morphologically possible. For descriptive grammars see Joki (1944), Künnap (1999), or Klumpp (2002) on the verb system.

For the present paper only the pre-shift documents were considered; examples come from the texts and the glossary in the Kamassisches Wörterbuch (Joki 1944), partly corrected on the base of Donner's unpublished manuscripts, as well as from a digitalized part of Donner's phonograph recordings (see Klumpp 2013). A couple of examples were taken from the older sources Spasskij (1806) and Castrén (1847).

\subsection{Productive operators in the valency slot}

Late pre-shift Kamas had a valency slot, situated between the simple, or non-productively derived verb stem to the left, and an aktionsart slot with suffixes recently grammaticalized from auxiliary constructions to the right (see Klumpp 2002, 2005 for details), e.g. (1).

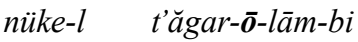

$$
\begin{aligned}
& \text { wife-2SG stab-INTR:REFL-RES-PST } \\
& \text { 'your wife has stabbed herself' [Ph.8: 103] }
\end{aligned}
$$

The valency slot had two productive operators: (i) the argument place decreasing suffix $-\bar{O}$, with its vowel-harmonic variants $-\bar{o}$ and $-\bar{o}$; and (ii) the argument place increasing suffix $-T \partial$, with the allomorphs -to after voiceless consonants, $-d \partial$ after voiced consonants, and $-t$ after full vowels. Both suffixes are of Proto-Uralic origin, the source of the intransitivizer $-\bar{O}$ is a deverbal reflexive formation with the Proto-Uralic marker * $\beta$ (Lehtisalo 1936: 38-42), and the transitivizer -Ta originates from the Proto-Uralic causative morpheme $* t$ (Lehtisalo 1936: 294-301). Both operators are considered produc- 
tive because they occur with stems which had been borrowed fairly recently from Turkic; e.g. the causative formation t'azar-do- 'make cure' is derived from a base verb tazar'cure, repair', which was borrowed from Sayan Turkic (cf. Qoybal t'azìr 'prepare, repair etc.', Joki 1952: 353).

Kamas had no alternative intransitivizers, but some older, non-productive transitivizers, e.g. $-l$ as in $\check{s} \breve{a}$ ? $b d \partial-l-$ 'hide (tr.)' from $\check{s} \breve{a}$ ' $b d \partial-$ 'hide (itr.)', or tüšs-l- 'teach' from tüšs'learn, get used to', or - $r$ as in minzz- $r$ - 'make boil' from minzz(-)l- 'boil'; both suffixes function productively in the Kamas sister language Selkup (for Southern Selkup see Kuznecova 1995: 53, 49). In addition to valency derivation, the resultative-perfective aktionsart formation of transitive verbs may enforce a transitive reading when applied to an intransitive verb, e.g. (2). The source of the resultative aktionsart suffix is an auxiliary ba?bdo- 'throw'.

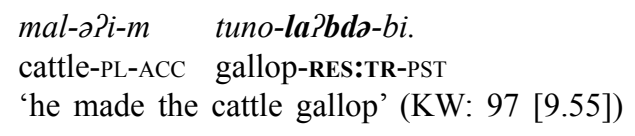

As the data suggest, the two productive valency operators seem to be subject to constraints on suffix order. First, they never occur recursively $\left({ }^{*}-\bar{O}-\bar{O},{ }^{*}-{ }_{-}-T ə\right)$. Second, they occur only in the combination "increase-decrease", i.e. $-T-\bar{O}$ as e.g. in (3c), but not vice versa. For the same constraint in Turkish, Haig (2000: 232) assumed a morphological rather than a semantic motivation. The same may hold for Kamas.
a. köz bü-nə üzə-bi
coal water-LAT descend-PST
'the coal fell into the water' (KW: 88 [1.5])

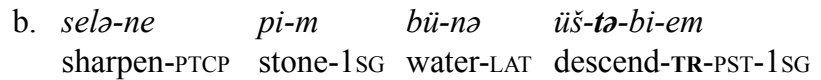
'I dropped my grindstone into the water' (KW: 85 [R.9])

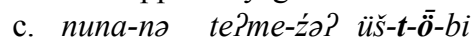
cliff-LAT rope-INS descend-TR-INTR:REFL-PST
'with a rope he let himself down the cliff' (KW: 93 [7.9-10])

Productive employment of valency morphology - or, depending on the tradition, voice, diathesis, or "genus verbi" morphology - is also characteristic of other languages of the area as reported e.g. for Xakas Turkic by Anderson (1998: 48), and for Mongolic by Janhunen (2012: 147); also the Yeniseic "version" in Kott (Castrén 1858; Werner 1997: 109-116) may be mentioned here. Differently from Kamas, Southern Selkup is reported to have more than just a few ambitransitive (Nichols et al. 2004: 153), or "neutral" verbs, as e.g. ettigu 'hang; hang up' (Kuznecova 1995: 41). A comparative areal study would be welcome in the future.

The structure of the paper is as follows. Section 2 inspects the functions of the valency decreasing operator $-\bar{O}$, and Section 3 the functions of the valency increasing operator $-T$. In both sections, combinations of the operators with attributive participles are discussed separately. The aim of the contribution is to give a concise account of the 
valency operators of Kamas, and to identify and classify their diverse readings as attested in the sources. In Section 4 the results are summarized.

\section{Functions of valency decreasing $-\bar{O}$}

\subsection{Anticausative, antipassive, passive, object suppressive, reflexive, and reciprocal verb formation}

The general function of the morpheme is to intransitivize transitive verbs, i.e. to decrease a verb's argument places from two (A-O) to one $(\mathrm{S}) .{ }^{1}$ This basic function has several different readings, depending on the semantics of the particular verb and the (morphological) context. An anticausative (or decausative) reading comes about where the $\mathrm{S}$ of the derived intransitive verb corresponds to an $\mathrm{O}$ of the transitive source verb, as e.g. in ardadar-ō- 'perish, go bad' from ardadar- 'spoil, damage' (KW:6a), ed-ö- 'hang (itr.), dangle' from edə- 'hang (up)' (KW: 17a), šü?d-ö- 'wake up (itr.)' from šü?də-r'wake up (tr.)' (KW:66a), or with transitive and intransitive 'gather' in (4a) compared to $(4 b){ }^{2}$

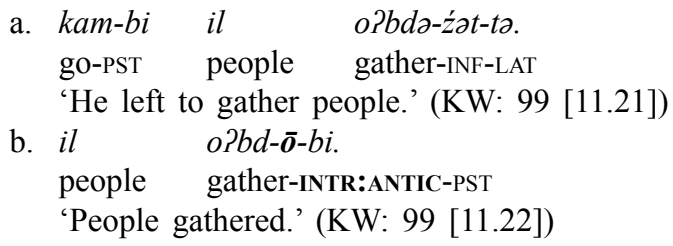

If the $\mathrm{S}$ of the derived intransitive verb corresponds to the $\mathrm{A}$ of the transitive source verb, an antipassive reading comes about (see the criteria by Dixon \& Aikhenvald 2000: 9). The action performed by an A of to?(bdo)- 'hit' as in (5a) involves a hand, fist, or an instrument (in case of (5a) this is a piece of wood). The action performed by the $\mathrm{S}$ of derived to?bdo- 'strike against, bump into' - in (5b) with an animate $\mathrm{S}$ referent, and in (5c) with an inanimate $S$ referent - does not involve any instrument, it is the $S$ itself that gets involved in a (figurative) bumping event. The semantic relationship between the two verbs reminds one of the German schlagen 'hit' : anschlagen 'bump into sth', or Turkish at- 'throw' : atıl- 'jump at' (Haig 2000: 220).
a. korbdo-ba ulu-tta to?-lu?-bi.
girl-ACC3sG head-ABL3SG hit-MOM-PST
'she hit her daughter on her head' (KW: 197 [M.44])

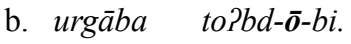
bear hit-INTR:ANTIP-PST

'A bear came up (lit.: bumped [into the moving protagonist]).' (KW: 88 [2.7])

${ }^{1} \mathrm{~A}$ (gent), O(bject), and S(ubject) refer to syntactic functions in the tradition of Dixon (1994).

2 (4b) is anticausative in a low-in-agentivity interpretation, where the gathering of an unspecified mass of people is perceived without any reference to the driving force, or their intentions. 


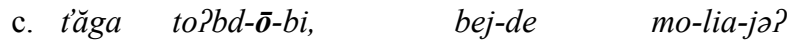 \\ river hit-INTR:ANTIP-PST cross-PTCP become-PRS-3PL}

'A river came up, they wanted to cross it.' (KW: 88 [1.2])

Correspondence of $\mathrm{S}$ of the derived intransitive verb to an $\mathrm{O}$ of the transitive source verb is characteristic not only for the anticausative, but also for the passive reading. The passive reading shows most clearly in a rarely attested construction, where the operator appears together with the predicative participle in $-m A$, as in (6b). This construction has a resultative passive meaning. However, a passive reading is also found in the verb 'burn', which is an old derivation of 'eat' (burn = being eaten by fire). The original passive relationship shows in (7a), where the $S$ of the burning event, the house, is "eaten up" by a fire. In (7b) however, where the $\mathrm{S}$ of burn is the fire itself, the passive relationship does not hold, and the reading of the formation in $-\bar{O}$ is one in terms of object suppression. ${ }^{3}$

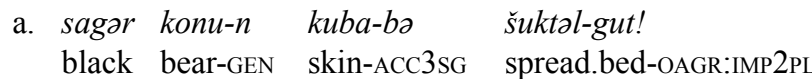

'Spread out a black bear's skin!' (KW: 88 [1.25])

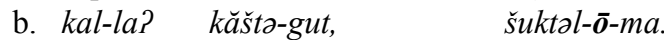
go-CVB invite-OAGR:IMP2PL spread.bed-INTR:PASS-PTCP

'Go and invite him, it [the bearskin] has been spread out.' (KW: 88, [1.27])

a. tura-m am- $\overline{\boldsymbol{o}}-b i$

house-1SG eat-INTR:PASS-PST

'my house burned down (lit.: has been eaten)' (KW: 5a)

b. $\check{s} \ddot{u} a m-\overline{\boldsymbol{o}}-l a ? b \partial$

fire eat-INTR:OSUP-PRS:DUR

'fire is burning' (KW: 5a)

Finally, a passive reading is lexicalized in the verb 'be bored' in (8b), which is derived from the transitive verb 'tie', as in (8a). There is no transitive backward formation 'bore somebody', which would be operated by the transitivizer -Ta, probably because such a formation would violate the constraint on suffix order (see above §1.2). Instead, as in (8c), we find the intransitive formation with a maleficent argument expressed as an indirect object. $^{4}$

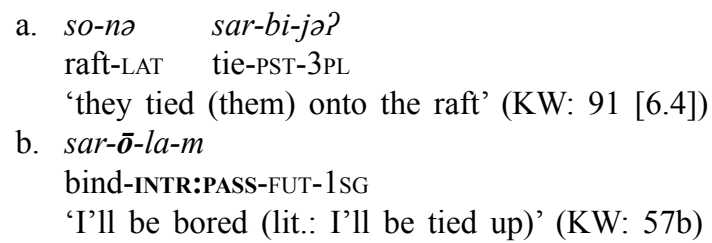

${ }^{3}$ Object suppression, in the understanding of this contribution, is an operation which, differently from the antipassive, has no consequence for the A.

${ }^{4}$ The syntactic function of măna '(to) me' in (8c) is actually ambiguous between an indirect and a direct object. Intuitively, I consider it an indirect object, but since (8c) is the only record with a maleficent of 'bore' in the Kamas sources, it remains uncertain if sarō- had acquired a secondary, transitive function. 


\section{c. tăn măna sar-̄̄-lām-bia-l \\ you me.oBL bind-INTR:PASS-RES-PST-2SG \\ 'you bore me (lit.: you've been tied up on me)' (KW: 57b)}

Where the $\mathrm{S}$ of the derived verb is identical to the $\mathrm{A}$ and to the $\mathrm{O}$ of the source verb, a reflexive reading comes about. This is the case in (9b) and (10b). Alternatively, an explicitly reflexive construal consists of the reduplicated reflexive pronoun bospos- 'self' and the underived verb, as in (10a). However, reflexivity may also be completely implicit, i.e. an underived verb may also have a reflexive reading, e.g. edo? 'hang (yourself) up!' in (9b). ${ }^{5}$ The reason for tolerating this ambiguity is probably that the derived verb $e d-\bar{o}$ - 'hang, dangle' is already booked for a non-transformative meaning, which would mean that aspectual properties rule over valency properties. Another case of implicit reflexivity shows in the causative-reflexive reading of the transitivizer - $T$ ə in $\$ 3.2$ below.
a. kuju-m săbəj?-bi, $\quad$ par-bi
brain-ACC pull.out-PST cook-PST
'she pulled the brain out and cooked it' (KW: 97 [9.34])

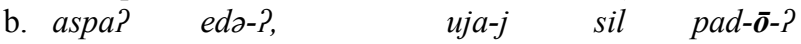
cauldron hang.up-IMP2SG meat-ADJ fat cook-INTR:REFL-IMP2SG
'Cauldron, hang up [yourself], meat and fat, cook yourself!' (KW: 96 [9.17])
(10) a. bospos-ta-bə t’ăgar-al-do
self-3SG-ACC3SG stab-FUT-OAGR:3SG
'she'll stab herself' (KW: 95 [8.98])
b. nüke-l t'ăgar-̄̄-lām-bi
wife-2SG stab-INTR:REFL-RES-PST
'your wife has stabbed herself' [Ph.8: 103]

Finally, for a reciprocal reading of the intransitivizer $-\bar{O}$, a non-singular subject is required. This may be either a dual subject as in (11), a plural subject as in (12b), or an additive subject as in (12c).

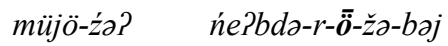

$$
\begin{aligned}
& \text { finger-INS pull-FRQ-INTR:RECP-OPT-1DU } \\
& \text { 'let's the two of us fingerwrestle!' (KW: 48a) }
\end{aligned}
$$
a. men tažว-m time-t-śa? t'abər-ja-t
dog squirrel-ACC tooth-3SG-INS seize-PRS-OAGR:3SG
'the dog seizes the squirrel with its teeth' (KW: 15a)

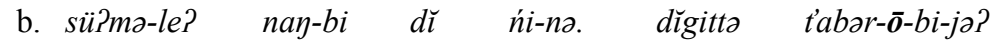 jump-CVB cling-PST DEM boy-LAT then Seize-INTR:RECP-PST-3PL
'She jumped and clung to the boy. Then they wrestled.' (KW: 93 [6.72-73])

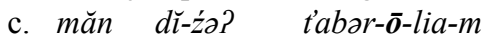
I DEM-INS Seize-INTR:RECP-PRS-1SG
'I'm wrestling with him' (KW: 76a)

${ }^{5}$ (9b) is from a fairy tale in which inanimate objects on command act like animates. The order 'hang up' addressed to a cauldron thus yields a reflexive reading 'hang up yourself/get hung up'. 


\subsection{Ambiguity of readings}

As seen in $\$ 2.1$, readings of the valency decreasing operator are fairly rich and varied. More than once they are ambiguous. The anticausative reading is not always distinguishable from the passive reading, so e.g. in (13b) both readings are, in principal, in place: the anticausative reading 'knife is sticking' is felicitous if observers simply state the fact that a knife is sticking in the heart of the dead person. The knife, however, arrived there in an act of stabbing, which was told earlier in the story (13a). Stressing the fact, that the knife had been stabbed, it is the passive reading which would be more felicitous. The present tense is possibly decisive here as it points rather to the anticausative reading, whereas a present passive reading 'is being stabbed' (at the time of observation) would not be felicitous. By contrast, in the riddle question in (14), the resultative past tense of sikt-ö- 'get strangled, get hanged' (from sǐktə- 'strangle, choke'), allows for a felicitous passive proper reading ('was hanged'). With an animate subject, however, a reflexive reading 'hanged itself' would also possible. ${ }^{6}$

a. tagaj-da süj-ganda mürbda-bi.

knife-3SG heart-LAT3sg push-PST

'He pushed his knife into her heart.' (KW: 96 [8.88])

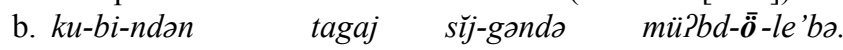

See-PTCP-LOC3PL knife heart-LOC3SG push-INTR:ANTIC/?PASS-PRS:DUR

'As they see, a knife is sticking/has been stabbed in her heart.' (KW: 96 [8.101])

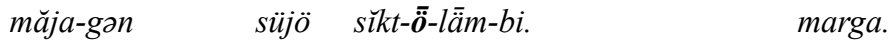

$$
\begin{aligned}
& \text { mountain-LOC bird strangle-INTR:PASS/REFL-RES-PST nipple } \\
& \text { 'On a mountain, a bird got strangled/strangled itself. - A nipple.' (KW: } 85 \text { [R2]) }
\end{aligned}
$$

With its multitude of readings the Kamas valency decreasing operator $-\bar{O}$ strongly reminds one of the Turkic passive morpheme, for which similar ambiguities as reported above are characteristic, cf. (15) from Turkish (Haig 2000).

(15) Turkish

Ayşe çek-il-di

A. draw/pull-PAss-PST

1. 'Ayşe (deliberately) drew back.' [reflexive]

2. 'Ayşe drew back (involuntarily through shock, pain, fear, etc.).' [anticausative]

3. 'Ayşe was pulled back (by someone).' [passive] (Haig 2000: 221)

\subsection{The operator $-\bar{O}$ in combination with the participle in $-N T A$}

The domain of the participle in -NTA, with its variants -na/-ne after vowels, $-d a /-d e$ after voiced consonants, and -ta/-te after voiceless consonants, is the attributive (verbal adjective) function. In older Kamas varieties, when suffixed to a transitive verb, the

${ }^{6}$ Whether the actual subject of the riddle question in (14), a bird, not associated with a protagonist function, actually qualifies as an animate reflexive subject, cannot be decided here. 
participle could function with P-orientation, i.e. as a passive participle, as in the $19^{\text {th }}$ century record in (16a). However, in $20^{\text {th }}$ century Kamas, P-orientation seems to be generally marked by the operator $-\bar{O}$ in front of the participle, whereas the neutral form triggers A-orientation as in (16b). The resulting complex passive participle in $-\bar{O} n A$ is illustrated in $(17 \mathrm{a}, \mathrm{b})$, and $(18 \mathrm{~b})$; in $(17 \mathrm{a})$ it appears with the primary transitive verb 'eat', and in (17b) with the derived transitive verb arom-do- 'clean' (from arzm- 'become clean'); (18a, b) illustrate the assumed opposition of the simple and the complex participle with an intransitive and its derived transitive verb: (18a) is S-oriented (the cauldron broke without an A), but (18b) is P-oriented (the sledge was broken by an A).

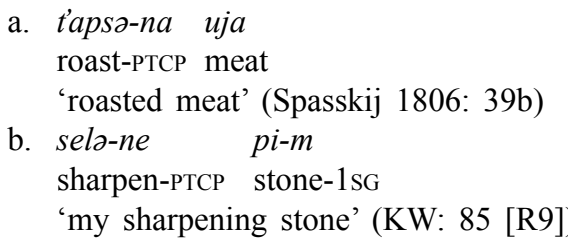
a. amor-ōna ine
eat-PTCP:PASS horse
'eaten horse' (KW: 178)
b. aram-d-ōna kola
become.clean-TR-PTCP:PAss fish
'gutted fish' (KW: 6a)
(18) a. băl-da aspa?
break-PTCP cauldron
'broken cauldron' (KW: 177)
b. băl-d-ōna narta
break-TR-PTCP:PAss sledge
'broken sledge' (KW: 178)

Despite the P-orientation as in the above examples (17b) and (18b), the participle formation with $-\bar{O}$ cannot be classified as a passive participle proper. For formations like $(19 \mathrm{a}, \mathrm{b})$, a segmentation in terms of "anticausative derivation + participle" seems more appropriate than an actual passive participle reading. Perhaps for (19a) ńeynö- 'melt (itr.); be melted', a passive reading (with the sun as A) would still be possible, but for (19b) păjdō- 'twine, twist; be twined, twisted' it rather is not: the twiner plant is not twined around a tree by any force but its own. Thus, the participle functions with $\mathrm{S}$ orientation and we deal with polysemy: the morpheme sequence $\{-\bar{O}-n A\}$ may be analysed either as a complex passive participle $-\bar{O} n A$, or as the participle of an intransitivized verb $-\bar{O}+-n A$.
a. e-ne ńegn- $\overline{\boldsymbol{o}}$-ne sire
NEG-PTCP melt-INTR:ANTIC-PTCP snow
'everlasting (lit.: not melting) snow' (KW: 48a)

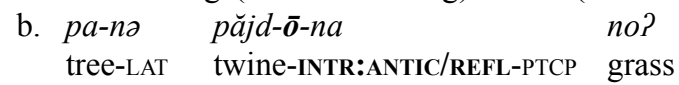
'twiner (lit.: grass which twines to tree)' (KW: 51b) 
The view that the operator $-\bar{O}$ is an independent segment preceding the participle receives further support by the examples with the verb ne?(bdo)- 'pull, tear' in (20) and (21). The a-examples illustrate the use of the underived transitive verb with direct objects. $^{7}$ While the participle formation in (20b) has P-orientation, the morphologically identical formation in (21b) shows S-orientation. While the first one is a passive participle, the second one can be called an object suppressive participle (see also footnote 3 ). In any case, it is the operator $-\bar{O}$ which brings in the passive or the object suppressive meaning, in the same way as it also produces the different readings in formation with finite verb forms. The glossings in (20b) and (21b) leave it undecided as to which analysis should be given preference.
a. essen uda-bə saj ńe?-lə-dən
child.PL.GEN hand-ACC3SG off tear-FUT-OAGR:3PL
'they will tear off children's hands' (KW: 91 [6.3])

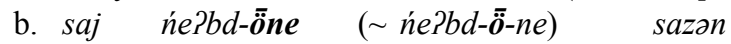
off tear-PTCP:PASS tear-INTR:PASS-PTCP paper
'torn up paper' (KW: 57)
a. kanza ńe?-lie-m
pipe pull-PRS-1SG
'I smoke (a) pipe' (KW: 48a)

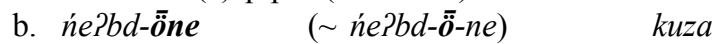
pull-PTCP:OSUP pull-INTR:OSUP-PTCP person
'smoker (lit.: a pulling person)' (KW: 47b)

\subsection{Non-productive imperfective verb formation}

Concluding this overview of the functions of the intransitive operator $-\bar{O}$, an old, most likely non-productive function needs also to be mentioned, namely the specification of imperfective verbs. This aspectual function is attested with initio-transformative verbs

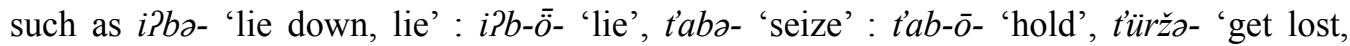

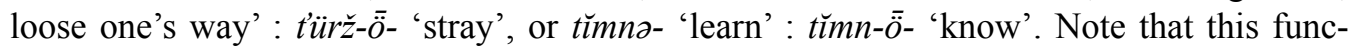
tion allows for transitive predication as in (22).

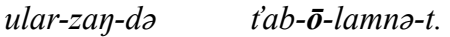

$$
\begin{aligned}
& \text { sheep-PL-3SG hold-IMPF-PRS:DUR-OAGR:3SG } \\
& \text { 'she's holding her sheep' (KW: } 95 \text { [8.93]) }
\end{aligned}
$$

The function of specifying imperfective meaning probably started from pairs like edo'hang (up)': ed-ö- 'hang, dangle', where the transitive member has a default perfective (transformative) and the intransitive member an imperfective (non-transformative) reading.

${ }^{7}$ In $(20 \mathrm{a}, \mathrm{b})$, the verb is preceded by the resultative binder $s a j$ 'off', the transitivity of the verb, however, is not due to this preverb as (21a) shows, where the bare verb also takes a direct object (albeit a possibly non-referential one). 
It cannot be excluded that this function was originally expressed by a different suffix that merged with the intransitivizer. The correlation of imperfective and intransitive compared to perfective and transitive, however, is also found in Southern Selkup deverbal derivation (Kuznecova 1995: 44), and in a cross-linguistic perspective, aspect is reported to interact with valency orientation (see e.g. Nichols et al. 2004: 184).

\section{Functions of valency increasing -To}

\subsection{Transitive and causative verb formation}

The general function of the valency increasing operator is increasing argument places, either from one to two, i.e. transitivization ( $\mathrm{S}>\mathrm{A}-\mathrm{O})$, or from two to three, i.e. causation $(\mathrm{A}-\mathrm{O}>\mathrm{A}-\mathrm{C}-\mathrm{O}){ }^{8}{ }^{8}$ With intransitive verbs, the outcome of derivation in $-\mathrm{To}$ is transitivization, i.e. adding an argument slot for an agent, as e.g. in (23b) which illustrates a controlled event, or in (24b) with an uncontrolled event. Frequently the morpheme occurs as a transitivizer of intransitive denominal verbs in $-m$, as e.g. aro- $m$ - 'become clean' (from arə 'clean') : arz-m-do- 'clean' (KW: 6a).
a. $k \ddot{z} z \quad b \ddot{u}-n ə \quad \ddot{z} z \partial-b i$
coal water-LAT descend-PST
'the coal fell into the water' (KW: 88 [1.5])
b. sela-ne pi-m bü-na üš-ta-bi-em
sharpen-PTCP stone-1sG water-LAT descend-TR-PST-1SG
'I dropped my grindstone into the water' (KW: 85 [R.9])
(24) a. nüke-t kal-la? tür-bi
wife-3sG go-CvB disappear-PST
'His wife went off' (KW: 96 [9.4])
b. akt'a-m tür-do-biö-m
money-ACC disappear-TR-PST-1SG
'I lost the money' (KW: 15b)

In complex transitive predicates with a resultative adjunct formed by the converb in $-J$, as in (25a-c), the transitivizer appears with the adjunct if the verb is intransitive, as in (25a). If the verb is primarily transitive, as in (25b), no transitive marking applies. However, possibly due to another morphological constraint, with intransitive verbs ending in $-t \partial$, or $-d \partial$, as e.g. păktz- 'burst' in (25c), also no transitive marking with the help of the operator $-T \partial$ is observed, even if it might be expected due to the transitivity of the complex predicate. ${ }^{9}$

\footnotetext{
${ }^{8}$ The term causation is reserved here for derivations that involve a causee (C).

${ }^{9}$ An attested transitive derivation of păktə- 'burst', is păktz-r- 'fire (a gun)' (KW: 50b).
} 
(25)
a. tii par-do-j ńe?b-biö-m
belt turn-TR-CVB pull-PST-1SG
'I pulled a belt around (me)' (KW: 15b, 51a, 177)

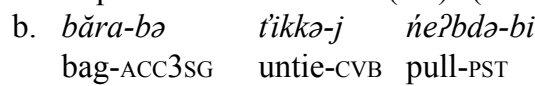
'he tore his bag open' (KW: 89 [2.54])
c. sima-bo păktə-j tït-lür-bi
eye-ACC3sG burst-CVB shoot-MOM-PST
'she shot his eye into pieces' (KW: 98 [10.27])

With transitive verbs, the operator assumedly also forms causative (curative, factitive) verbs with the three argument places of causer, causee, and patient. The only attested instance in the Kamas corpus, however, is (26b), in which no causee is expressed.
$\begin{array}{lll}\text { a. tăn } & \text { sima-l } & \text { t'azar-la-dan } \\ \text { you } & \text { eye-2sG } & \text { cure-FUT-OAGR:3PL }\end{array}$
'They will cure your eye' (KW: 99 [11.38])
$\begin{array}{lll}\text { b. măn } & \text { sima- } m & \text { t'azar-do-lo- } m \\ \text { I } & \text { eye-1SG } & \text { cure-TR:CAUS-FUT-1SG }\end{array}$
'I will have my eye cured' (KW: 99 [11.36])

One of the functions reported for transitivizers is the applicative function, where a direct object is introduced to an underlying intransitive verb, or in an underlying transitive clause a peripheral argument becomes a direct object (Dixon \& Aikhenvald 2000: 13-14; Aikhenvald 2011: 93-97). In Kamas, there is a construction in which a goal referent is promoted to direct object function, as with 'fire' in (27a) compared to (27b). The operator $-T \partial$ is not required in this context, the promoted object in (27b) occurs with the same underived verb heN- 'put' as in the underlying construction in (27a). However, the applicative function can be observed in the resultative $J$-converb adjunct in (28a), and possibly also in the $J$-converb pardaj 'surrounding' met already in (25a), now functioning as a postposition in (28b) (there is forest around me $>$ I'm surrounded by forest).

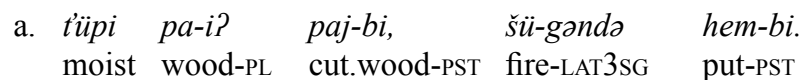

'She cut moist wood and put it onto the fire.' (KW: 90 [3.12])

b. šü kaza-źo? hem-bi.

fire bark-INS put-PST

'She put bark on the fire/made the fire with bark.' (KW: 197 [M.26])
a. pa-m paral-d-i kük no? özer-bi.
tree-ACC spin-TR:APPL-CVB green grass grow-PST
'Green grass grew around the tree (lit.: surrounding the tree).' (KW: 87 [R30])
b. măna par-do-j $p a$
I.OBL turn-TR:APPL-CVB wood
'I'm surrounded by forest' (KW: 177) 


\subsection{Causative-reflexive and control readings of the transitivizer}

In intransitive predicates, where no $\mathrm{O}$ referent is available, the valency increaser $-T \partial$ has readings of reflexive causativity and control; especially in motion predicates. First, consider (29), which can still be understood as a proper instance of causation: the galloping referent is not the girl, but the horse she's riding, i.e. she has her horse galloping.

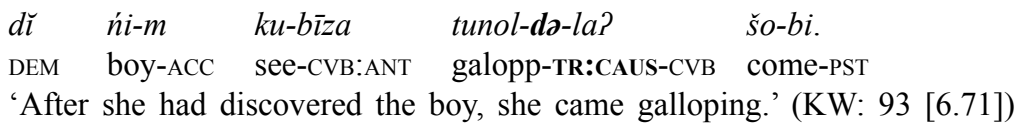

(30c) introduces another instance of the transitivizer with an intransitive movement verb; the underived verb 'glide' functions either in an uncontrolled event as in (30a), or in a controlled one as in (30b). Gliding on skis as in (30c) is also a controlled event, but now the transitive operator shows. ${ }^{10}$ The default $\mathrm{P}$ of the making-glide event is either the skis the A is standing upon, which yields a reading of a transitive event proper as in (29), or it is the A themselves, an interpretation which yields an implicit reflexive reading of the formation.
a. $t \dddot{u} \quad n \bar{a} n z \partial-l i a$
ground glide-PRS
'the ground is sliding (in a landslide)' (KW: 43b)
b. ńi? nānza-la? mĭy-ge
eagle glide-CVB go-PRS
'the eagle glides' (KW: 43b)
c. nānzo-r-do-lia-m
glide-FRQ-TR:CAUS.REFL/CONT-PRS-1SG
'I glide (e.g. with skis)' (KW: 43b)

Where the causative-reflexive reading occurs with verbs which otherwise mean uncontrolled motion events, such as e.g. fall, or sink, a control reading comes about. Reflexive uses of the German causative construction with lassen plus infinitive, e.g. ich lasse mich fallen 'I make myself fall', have the function of expressing untypical control (Koo 1997: 52). Control is also mentioned as a possible agent-related non-valency-increasing effect of causative morphology by Aikhenvald (2011: 101, 137). A Kamas case in question is 'disappear', as illustrated in (31a-c). ${ }^{11}$ Derived tür-do- 'loose (make disappear)' as in (31b), is the transitive equivalent of tür- 'disappear', as in (31a). In (31c) the transitive formation has again a reflexive reading, and the suffix may be interpreted as a marker of control: the duck controls an event of its own immerging to the degree that it disappears from the sight of the observer. Again, as in (30c), the reflexive component remains completely implicit. It is unclear to what degree control marking in resultative adjuncts formed by the converb in $-J$, as in (31c), is obligatory in Kamas, be-

\footnotetext{
${ }^{10}$ The stem nānzar- 'glide' in (28c) shows a non-productive frequentative aktionsart marker $-r$, which has no effect on the valency of the verb.

${ }^{11}(31 a, b)$ repeat $(24 a, b)$.
} 
cause the construction is not attested frequently. The pattern is also known in South Siberian Turkic; cf. (32) from Qacha, in which an intransitive resultative adjunct contains a causative marker, marking control as in the Kamas example (31c).
a. nüke-t kal-la? tür-bi.
wife-3SG go-CVB disappear-PST
'His wife went off.' (KW: 96 [9.4])
b. akt'a-m tür-do-biö- $m$
money-ACC disappear-TR-PST-1SG
'I lost the money.' (KW: 15b)
c. $n a ? b$ bü-nə tür-do-j pă?-lu?-lia
duck water-LAT disappear-TR:REFL-CVB immerge-MOM-PRS
'the duck plunged into the water' (KW: 53b)

(32)

$$
\text { Qacha }
$$

\begin{tabular}{|c|c|c|}
\hline in & $\begin{array}{l}s l \gamma-\breve{a r} r-a \\
\text { emerge-CAUS-CVB }\end{array}$ & $\begin{array}{l}j \ddot{u} g-\ddot{u} r \\
\text { run-CVB }\end{array}$ \\
\hline
\end{tabular}

'it emerged from the sea' (Radloff 1867: 528, line 935)

\subsection{The operator $-T$ o in combination with the participle in $-N T A$ : the causee participle}

For the intransitivizer $-\bar{O}$ in connection with the participle in $-N T A$ of a transitive verb, it has been stated above in $\$ 2.2$ that this formation may read as a P-oriented participle. A-orientation, however, was found with the bare participle, as e.g. in (16b), repeated below in (33a). After closer inspection of this example, one may find that it has an instrumental reading, i.e. it is not the stone itself which sharpens, but an A using it to sharpen an object (e.g. a knife). Two more cases are $(33 b, c)$. These formations do not differ from instrumental participles of intransitive verbs, as in (33d, e). However, this impression does not hold if one considers more formations of instrumental participles from transitive verbs. Frequently, if not in the majority of cases, the participle formation involves causative marking by $-T \partial$, as in (34b) and (35b). Thus, contrasting the use of the two different operators with identical verbs, as in (35a) compared to (35b), one finds the valency decreasing operator marks P-orientation, but the valency increasing operator marks C-orientation. ${ }^{12}$

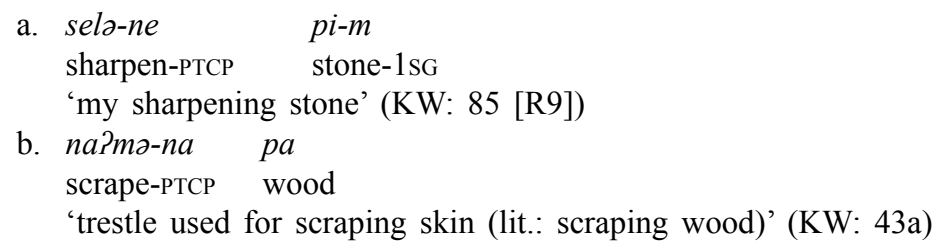

12 For (33c) it may be assumed that the verb stem in -də may prohibit suffixation with $-T \partial$, cf. the same constraint in $(25 \mathrm{c})$ above. 


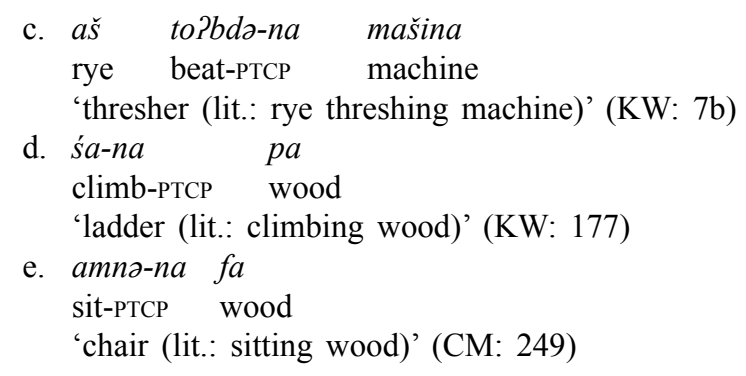

(34) a. šoška t’ü tŭl-lie

pig ground dig-PRS

'the pig churns up the ground' (KW: 16b)

b. $t \dddot{u}$ tull-do-ne baza

ground dig-TR:CAUS-PTCP iron

'plough (lit.: ground digging iron)' (KW: 16b)
a. amor- $\overline{\boldsymbol{o}}-n a$ ine
eat-ITR:PASS-PTCP horse
'eaten horse' (KW: 178)
b. amor-do-na t'ardo
eat-TR:CAUS-PTCP board
'eating board (table)' (KW: 5b)

The instrumental reading of the causee-participle in -TənA is less clear where the head noun is animate, as in $(36 \mathrm{a}, \mathrm{b})$. In these cases, the operator - Ta could also be interpreted as marking A-orientation (the child sucks the breast, the person herds the cattle). However, both cases equally allow for a causee reading too, i.e. a child who is made suck the breast, and a person who is made herd cattle.
a. nüjü-m emer-do-ne eši
breast-ACC suck-TR:ACT/CAUS-PTCP child
'suckling (lit.: breast sucking child)' (KW: 20a)
b. mal kadar-do-na kuza
cattle herd-TR:ACT/CAUS-PTCP person
'herder (lit. person made herding the cattle)' (KW: 37b)

A further reading of the formation -TanA is the causative-passive reading. It comes about in a causative-permissive context without overt direct object, where in consequence, the action is directed towards the subject: it permits negative actions such as betray, steal, beat happening to themselves (Nedyalkov \& Sil'nickiy 1969: 39). An attested case in Kamas is (37). The translation points to P-orientation of the participle, and one would rather expect the valency decreaser $-\bar{O}$ instead of the increaser $-T \partial$. Again, Turkic offers similar semantic relationships, e.g. the Tuvan causative formation ölür-t- (from ölür'kill'), which means either 'make kill' (causative proper), or 'be killed' (causative-passive) (Johanson 1998: 55-56).

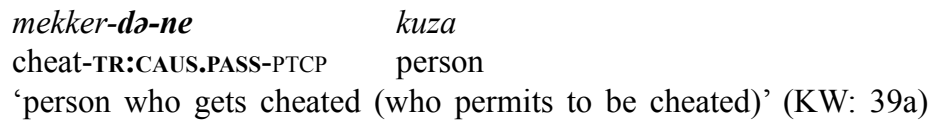


An additional interpretation of causee participles is that the referents of the participles act regularly, or in case of the instruments, are applied in a particular function regularly. Besides expression of "increase in manipulative effort, intentionality, volitionality and control", iterative action is also listed as a possible action-related not-valency-increasing effect of causative morphology by Aikhenvald (2011: 101, 137). In closely related Selkup, there is a deverbal verb derivation which is classified as characterizing aktionsart, and the morpheme in question -ty is the etymologically cognate of the Kamas argument increaser, e.g. Selkup (Taz) cāsympy- 'smirk' : cās-tympy- 'have the habit of smirking',

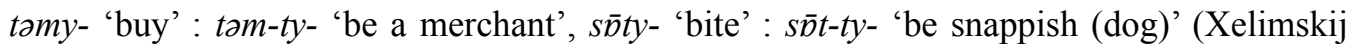
et al. 1980: 233). For (38) and (39b), the characterizing function seems an appropriate reading: while so far the causee participles maintained transitive semantics, this is hardly detectable in the local noun in (38), and even less in the intransitive formation in (39b).

$$
\begin{aligned}
& \text { uzar-do-na ma? } \\
& \text { forge-TR?:CHAR-PTCP } \quad \text { house } \\
& \text { 'blacksmith's shop' (KW: 81b) }
\end{aligned}
$$
a. men orar-la?ba
dog bark-PRS:DUR
'a/the dog is barking' (KW: 49b)
b. orar-do-na men
bark-TR:CHAR-PTCP dog
'barking dog (lit. dog making itself bark, i.e. a dog which barks a lot)' (KW: 49b)

Therefore, ambiguity of readings is a property not only of the valency decreaser (see $\S 2.2$ ), but also of the valency increaser. More than one possible reading is e.g. detectable in the interpretation of the formation in (40).

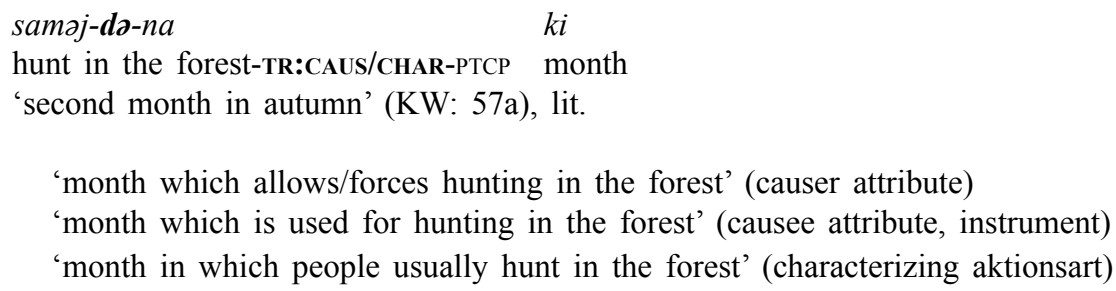

\section{Summary}

The above examination of attestations of the Kamas morphemes $-\bar{O}$ and $-T \partial$ in early $20^{\text {th }}$ century sources revealed that they are productive valency operators with a considerably broad spectrum of functions; or more exactly, with a broad spectrum of readings of their basic functions of valency decrease (intransitivization) and increase (transitivization). For the valency decreasing operator $-\bar{O}$, anticausative, antipassive, passive, object suppressive, reflexive and reciprocal readings were identified in $\$ 2.1$. The ambiguity (or multifunctionality) of the operator was found to be similar to the Turkic passive forma- 
tion in $\S 2.2$. For its combination with the (attributive) participle in -NTA, it was discussed in $\S 2.3$ whether this combination should be analysed as a complex passive/object suppressive-participle (depending on its O- or A-orientation), however, as there is no obvious grammaticalization, an analysis in terms of an independent valency slot in non-finite forms seems feasible. The grammaticalization of complex participles, however, is certainly an option in this constellation. Finally, the operator was observed as an imperfectivizer of initio-transformative verbs, a function assumed to be non-productive in the examined sources.

The valency increasing operator - To was found to derive transitive from intransitive, and causative from transitive verbs in $\S 3.1$. It further marks control in causatives formed from intransitive movement predicates, which may then get a reflexive reading (\$3.2). For Kamas and South Siberian Turkic, a parallel pattern of control marking in movement predicates was observed. In formations with the participle in $-N T A$, the operator $-T$ o often has C-orientation with readings of causative-instrumental and causative-passive (§3.3). In addition, the causee-participle was found in a function which corresponds to the so-called characterizing aktionsart in the sister language of Kamas, Selkup. In addition, the formations with the valency increaser are also subject to ambiguity.

The readings encountered are summarized in the following table, with numbers referring to the examples in the text. A question mark preceding an example number means it is ambiguous, and the same number occurs more than once in the Table 1.

Table 1: Readings of Kamas valency operators

\begin{tabular}{c|c|c}
\hline Operator & Function/reading & Example numbers \\
\hline$-\bar{O}$ & anticausative & $4 \mathrm{~b} / 19 \mathrm{a} / ? 13 \mathrm{~b}$ \\
& antipassive & $5 \mathrm{~b}, \mathrm{c}$ \\
& passive & $6 \mathrm{~b} / 7 \mathrm{a} / 8 \mathrm{~b}, \mathrm{c} / 17 \mathrm{a}, \mathrm{b} / 18 \mathrm{~b} / 20 \mathrm{~b} / ? 13 \mathrm{~b} / ? 14 \mathrm{~b}$ \\
& object suppressive & $7 \mathrm{~b} / 21 \mathrm{~b}$ \\
& reflexive & $9 \mathrm{~b} / 10 \mathrm{~b} / 19 \mathrm{~b} / ? 14 \mathrm{~b}$ \\
& reciprocal & $11 / 12 \mathrm{~b}, \mathrm{c}$ \\
\hline \multirow{2}{*}{$-T \partial$} & imperfective & 22 \\
& transitive & $23 \mathrm{~b} / 24 \mathrm{~b} / 25 \mathrm{a} / 31 \mathrm{~b}$ \\
& causative & $26 \mathrm{~b} / 29$ \\
& applicative & $28 \mathrm{a}, \mathrm{b}$ \\
& causative-reflexive/control & $30 \mathrm{c} / 31 \mathrm{c} / ? 40$ \\
& causative: causee participle & $34 \mathrm{~b} / 35 \mathrm{~b}, 36 \mathrm{a}, \mathrm{b} / ? 40$ \\
& causative-passive & 37 \\
& characterizing & $38 / 39 \mathrm{~b} / ? 40$ \\
\hline
\end{tabular}

Further study should investigate the cross-linguistic development in the Southern Siberian area, i.e. discover which of the Sayan Samoyed, Turkic, Mongolic, and Yeniseic 
languages restructured their valency operator system under the influence of one or several contact languages. For Kamas, it can be stated that its valency decreasing operator and the Turkic passive operator function highly similarly. Moreover, the Kamas morpheme in question, despite its Proto-Uralic origin, seems to be an innovation which has no close parallel in Northern Samoyed or in Selkup. Thus, adjustment to a Turkic pattern can be assumed for Kamas. The valency increasing function is less clear, because Turkic shows a difference between transitive and causative operators that seems to be absent from Kamas. Finally, besides the Turkic-Samoyed interaction, the amount of Yeniseic (more exactly Kott and Arinic) substrate concerning the domain of valency in the languages of the Eastern Sayan at the beginning of the $20^{\text {th }}$ century has not yet been investigated.

\section{Abbreviations}

ABL - ablative case; ACC - accusative case; ACT - active; ADJ - adjective derivation; ANT anterior; ANTIC - anticausative; ANTIP - antipassive; APPL - applicative; C - causee; CAUS - causative; CHAR - characterizer; CONT - control marker; CVB - converb; DEM - demonstrative pronoun; DU - dual number; DUR - durative aktionsart; FRQ - frequentative aktionsart; FUT - future tense; GEN - genitive case; IMP - imperative mood; IMPF - imperfective aspect; INF - infinitive; INS instrumental case; INTR - intransitive; LAT - lative case; LOC - locative case; MOM - momentaneous aktionsart; NEG - negative auxiliary; OAGR - object agreement marker; OBL - oblique case; OPT optative mood; OSUP - object suppressive voice; PASS - passive; PL - plural number; PST - past tense; PTCP - participle; QP - interrogative particle; RECP - reciprocal; REF - reflexive; RES - resultative aktionsart; SG - singular number; TR - transitive.

\section{References}

Aikhenvald, Alexandra Y. 2011. Causatives which do not cause: non-valency-increasing effects of a valency-increasing derivation. In Aikhenwald, Alexandra Y. \& Dixon, R.M.W., Language at large. Essays on syntax and semantics, 86-142. Amsterdam: Brill.

Anderson, Gregory D. S. 1998. Xakas (Languages of the world: Materials 251). München-New Castle: Lincom Europa.

Castrén, Matthias A. 1847. Manuscripta Castréniana XIX. Samoiedica 13: Kamass-Samoiedica. Manuscript. Library of the University of Helsinki.

Castrén, Matthias A. 1858. Jenissej-ostjakische und kottische Sprachlehre. Herausgegeben von Anton Schiefner (Nordische Reisen und Forschungen 12). Sankt Petersburg: Kaiserliche Akademie der Wissenschaften. (Reprint 1969, Leipzig: Zentralantiquariat der DDR.)

$\mathrm{CM}=$ Castrén 1847.

Dixon, R.M.W. 1994. Ergativity. Cambridge: Cambridge University Press.

Dixon, R.M.W. \& Aikhenwald, Alexandra Y. 2000. Introduction. In Dixon, R.M.W. \& Aikhenwald, Alexandra Y. (eds.), Changing valency: Case studies in transitivity, 1-29. Cambridge: Cambridge University Press.

Haig, Geoffrey. 2000. Towards a unified account of Passive in Turkish. Turkic Languages 4. 215-234.

Janhunen, Juha. 2012. Mongolian. Amsterdam-Philadelphia: John Benjamins.

Johanson, Lars. 1998. The Structure of Turkic. In Johanson, Lars \& Csató, Éva Á. (eds.), The Turkic Languages, 30-66. London-New York: Routledge.

Joki, Aulis J. 1944. Kai Donners Kamassisches Wörterbuch nebst Sprachproben und Hauptzügen der Grammatik (Lexica Societatis Fenno-Ugricae VIII). Helsinki: SUS.

Joki, Aulis J. 1952. Die Lehnwörter des Sajansamojedischen (Mémoires de la Société Finno-Ougrienne 103). Helsinki: SUS. 
Klumpp, Gerson. 2002. Konverbkonstruktionen im Kamassischen (Veröffentlichungen der Societas Uralo-Altaica 58). Wiesbaden: Harrassowitz.

Klumpp, Gerson. 2005. Aspect markers grammaticalized from verbs in Kamass. Acta Linguistica Hungarica 52(4). 397-409.

Klumpp, Gerson. 2013. On Kai Donner's phonograph records of Kamas. Finnisch-Ugrische Mitteilungen 37. 45-59.

Koo, Myung-Chul. 1997. Kausativ und Passiv im Deutschen. Frankfurt a. M.-Berlin: Lang.

Künnap, Ago 1999. Kamass (Languages of the world: Materials 185). München-Newcastle: Lincom Europa.

Kuznecova, Nadezhda G. 1995. Grammaticheskie kategorii yuzhnosel'kupskogo glagola. Tomsk: Izd. Tomskogo Universiteta.

$\mathrm{KW}=$ Joki 1944 .

Lehtisalo, Toivo. 1936. Über die primären ururalischen Ableitungssuffixe (Mémoires de la Société Finno-Ougrienne 72). Helsinki: SUS.

Nedyalkov, Vladimir P. \& Sil'nickiy, Georgi G. 1969. Tipologiya morfologicheskogo i leksicheskogo kauzativov. In Xolodovich, Aleksandr A. (ed.), Tipologiya kauzativnyx konstrukcij, 20-50. Leningrad: Nauka.

Nichols, Johanna \& Peterson, David A. \& Barnes, Jonathan. 2004. Transitivizing and detransitivizing languages. Linguistic Typology 8(2). 149-211.

$\mathrm{Ph}=$ sound file SU0233 at the Archive of Dialects and Related Languages of Estonian at Tartu University. www.murre.ut.ee/arhiiv.

Pritsak, Omeljan. 1959. Das Abakan- und Čulymtürkische und das Schorische. Anhang: Das Kamassische. In Dény, Jean et al. (eds.), Philologicae Turcicae Fundamenta. Vol. I. 598-640. Wiesbaden: Franz Steiner.

Radloff, Wilhelm. 1867. Proben der Volksliteratur der türkischen Sprachen Süd-Sibiriens, II. Teil, St. Petersburg.

Spasskij, Grigorij I. 1806. Slovar' Yazyka Koybal'skago. In Potapov, L. P. 1957. Zum Problem der Herkunft und Ethnogenese der Koibalen und Motoren. Journal de la Société Finno-Ougrienne 59. 33-56.

Werner, Heinrich. 1997. Abriß der kottischen Grammatik (Tunguso Sibirica 4). Wiesbaden: Harrassowitz.

Xelimskiy, Evgeniy A. \& Kuznecova, Ariadna I. \& Grushkina, Elena V. 1980. Ocherki po sel'kupskomu yazyku. Tazovskiy dialekt. Tom 1. Moskva: Izd-vo Moskovskogo universiteta. 